\title{
Holsteins in Puerto Rico: II. Influence of Lac- tation Length, Days Dry, Days Open, and Calving Interval on Production Traits ${ }^{1}$
}

\author{
I. K. Camoens, R. E. McDowell, L. D. VanVleck, and \\ J. D. Rivera Anaya ${ }^{2}$
}

\begin{abstract}
Records of high grade or purebred Holsteins in 62 herds on DHIA recording in Puerto Rico were used to determine phenotypic correlations of lactation length, days dry prior to lactation, days open during lactation, and interval from previous parturition (calving interval) to lactation, milk and fat yields, and fat percent. Both milk and fat yields had a significant $(\mathrm{P}<.05)$ positive phenotypic correlation with lactation length, calving interval, and days open (0.178 to 0.658), but fat percent had a low relation to these traits $(-0.023$ to +0.014$)$.

Lactation length, dry period, days open, and calving interval were regressed on milk yield, fat yield, and fat percent. The combined contribution of these variables to variation in milk yield was $44.4 \%$. Days open, days dry, and calving interval accounted for only $13.4 \%$ of the variation in milk yield. Days dry and days open together accounted for $9.6 \%$ of the variation, and days dry, plus calving interval, made up $6.0 \%$ of the variation. The values for fat yield were slightly lower but followed a similar pattern as for milk yield. The four variables combined contributed only $0.23 \%$ to the variance in fat percent. Total milk yield and fat yield were influenced by lactation length, calving interval, and days dry in descending order of magnitude. Days open had comparatively little influence on either milk or fat yields. Length of dry period influenced fat percent more than any other variable but to little extent. Since the majority of the variation in milk and fat yields attributed to the four variables was due to lactation length, it appears that in Puerto Rico selection with emphasis on lactation yields is unlikely to decrease fertility.

${ }^{1}$ Manuscript submitted to Editorial Board June 3, 1975.

${ }^{2}$ Veterinary Officer, Kuantan, Pahang, West Malaysia; Professor, Department of Animal Science, Comell University, Ithaca, N.Y. and Consultant, University of Puerto Rico, Mayagüez and Río Piedras, P. R.; Professor, Department of Animal Science, Cornell University, Ithaca, N.Y.; and former Director of Department of Animal Husbandry, Agricultural Experiment Station, University of Puerto Rico, Rio Piedras, P. R. The authors are grateful to the staff of the Animal Improvement Programs Laboratory, USDA, Beltsville, Md., and to Puerto Rico DHIA officers, for making the DHIA records available.
\end{abstract}




\section{INTRODUCTION}

The relationships between lactation yields and lactation length, days dry prior to lactation, days open during lactation, and previous calving interval have been documented for Holsteins in the temperate regions. Such reports from the tropics are scarce, especially studies involving a number of herds. Since the main objective of a dairy enterprise is maximizing profits through increased milk and fat yields per unit of time, some indication of performance from readily measurable events, such as previous calving interval and days dry and current days open could well assist in decision making. This would apply especially to early culling of low producing cows.

This study deals with the influence of lactation length, days dry, days open, and calving interval on lactation performance of Holsteins in a tropical environment.

\section{PROCEDURE}

The data consisted of 33,950 lactation records from 62 herds on DHIA recording in Puerto Rico. Preliminary edits of the data removed the following: 1) all records not terminated normally, 2) all records exceeding 305 days, and 3) records $<60$ days. A fuller description of the data and the screening procedures has been given in Part I (2).

Since calving intervals could be obtained only from repeat lactations, it was necessary also to drop cows with only one completed lactation. This left 5,002 lactations with milk and fat yields, lactation length, days dry, days open, and calving interval recorded.

The approach was to relate milk and fat yields and fat percent to other variables by regression analysis. The independent variables were dropped singly and in pairs to determine their relative importance with regard to the dependent variables investigated.

The model used was:

$$
\begin{gathered}
Y=\alpha+b_{1} X_{1}+b_{2} X_{2}+\underset{3}{b_{3} X_{3}+b_{4} X_{4}}+\text { residual deviation from } \\
\text { regression }
\end{gathered}
$$

where;

$$
\begin{aligned}
& Y=\text { milk yield, fat yield, or fat percent; } \\
& \alpha=\text { intercept; } \\
& X_{1}=\text { lactation length; } \\
& X_{2}=\text { days dry prior to the lactation; } \\
& X_{3}=\text { days open during the lactation; } \\
& X_{4}=\text { calving interval prior to the lactation. }
\end{aligned}
$$


Correlation coefficients, $F$-ratios, squared multiple correlation coefficients $\left(R^{2}\right), t$ statistics, and standard partial correlation coefficients (S.P.R.) were calculated in the conventional way.

\section{RESULTS AND DISCUSSION}

\section{PHENOTYPIC CORRELATIONS}

Phenotypic correlations between the variables are in table 1. Milk and fat yields were positively correlated with lactation length, days open, and calving interval. These correlations were significant $(\mathrm{P}<.05)$. The relationship of milk and fat yields to previous dry period was negative but did not differ significantly from zero. Fat percent was not significantly correlated with lactation length, days dry, days open, or calving interval.

Data from the United States also showed a significant positive correlation between lactation length and milk production (1). One report mentions correlation coefficients of from 0.50 to 0.60 between lactation length and milk yield (7). A positive correlation of 0.31 has been reported between service period and milk yield (13). Correlations of 0.19 and 0.21 have been reported between calving interval and milk yield (10). The similarity between these figures and those obtained from the data from Puerto Rico is striking.

Lactation length had a significant positive correlation with current days open but was negatively correlated with previous dry period (table 1). Previous calving interval was positively correlated with lactation length, previous dry period, and current days open. The correlations were significant $(\mathrm{P}<.05)$. A report from the temperate zone $(12)$ gave a higher correlation (0.99) between days open and calving interval. Correlation between days open and previous dry period was not significant.

\section{REGRESSION COEFFICIENTS}

All the regression coefficients $(\beta)$ with four, three, and two independent variables (lactation length, days dry, days open, and calving interval) were significant $(\mathrm{P}<.05$ ) for milk yield (table 2$)$. The squared multiple correlation coefficients $\left(R^{2}\right)$ from these regressions tended to vary, which indicates the relative importance of the independent variables to milk yield. The combinations with lactation length as an independent variable yielded higher $F$-ratios than other combinations and $R^{2}$ values of 43.3 to $44.4 \%$. Days open, days dry, and calving interval together explained only $13.4 \%$ of the variation in milk yield, while the inclusion of lactation length raised this to $44.4 \%$. Days dry and days open together accounted for $9.6 \%$ of the variation, and days dry and calving interval together accounted for only $6.0 \%$. Exclusion of days open from the 
regression yielded a value for $R^{2}$ identical to that obtained with all four variables in the equation (44.4\%). This suggests that days open had very little influence on milk production, which could not be explained by the other variables. Similarly, the exclusion of either days dry or calving interval alone from the regression did not reduce the $R^{2}$ value to any great extent ( 43.4 vs $44.2 \%$ ). It appears that milk yield is influenced by lactation length, calving interval, and days dry in descending order of magnitude. The regression coefficients, $t$ statistics, and standard partial regression coefficients associated with the regressions support this conclusion (table 2). Quantitatively, the regression equations may be interpreted to mean that an increase of 1 day in lactation length is equivalent to adding about $44 \mathrm{lb}$ of milk; a day increase in calving interval would be expected to increase milk yield approximately $4 \mathrm{lb}$. One day increase in the length of the previous dry period would decrease

TABLE 1.-Phenotypic correlations between various traits

\begin{tabular}{lrccc}
\hline \multicolumn{1}{c}{ Trait } & Days dry & Days open & Lactation length & Calving interval \\
\hline Milk yield & -0.059 & $0.302^{*}$ & $0.658^{*}$ & $0.178^{*}$ \\
Fat yield & -.042 & $.294^{*}$ & $.607^{*}$ & $.181^{*}$ \\
Fat \% & .039 & .010 & -.023 & .014 \\
Days dry & & .027 & $-.099^{*}$ & $.492^{*}$ \\
Days open & & & $.428^{*}$ & $.141^{*}$ \\
Lactation length & & & & $.135^{*}$ \\
\hline
\end{tabular}

$* \mathrm{P}<.05$

milk yield by about $2.5 \mathrm{lb}$. The contribution of days open was negligible (table 2).

There is very little evidence in the literature of attempts to relate milk yield to the variables evaluated in the same fashion as in the present study. Using somewhat similar procedures, up to $62 \%$ of the variation in milk yield could be due to the length of lactation in Zebu cattle (11), but between 20 and $30 \%$ in U.S. herds $(3,15)$.

From most studies it appears that length of dry period has some influence on production levels. In one report (5), dry period and calving interval had a significant relationship to FCM production per day of life. Another report showed that previous dry period accounted for less than $1 \%$ of the total variation in milk yield (20). In India length of dry period was an important factor (14). The values from the present study appear intermediate to those in the literature. The difference in findings may have arisen because of the variability in the length of dry period considered and because lactation length was not considered as a joint variable in other analyses as it was in the current study. 
TABLE 2.-Regression coefficients for predicting milk yield (dependent variable) from various combinations of lactation length, days dry, days open, and calving interval (independent variables) and test of significance

\begin{tabular}{|c|c|c|c|c|c|c|c|c|}
\hline Combination & $\alpha^{2}$ & $\begin{array}{c}\text { Lactation } \\
\text { length }\end{array}$ & $\begin{array}{c}\text { Days } \\
\text { dry }\end{array}$ & $\begin{array}{l}\text { Days } \\
\text { open }\end{array}$ & $\begin{array}{l}\text { Calving } \\
\text { interval }\end{array}$ & $\begin{array}{c}\text { Denominator } \\
\text { d. } \ell^{2}{ }^{2}\end{array}$ & $F$-ratio & $R^{2} \%^{3}$ \\
\hline 1 & -4378 & & & & & 4998 & $997.8^{*}$ & 44.4 \\
\hline$\beta \dagger$ & & 44.0 & -2.6 & 0.7 & 3.9 & & & \\
\hline $\mathrm{t}+\dagger$ & $18.0^{*}$ & $52.8^{*}$ & $4.5^{*}$ & 1.5 & $9.4^{*}$ & & & \\
\hline S.P.R. $+\dagger \dagger$ & & .63 & -.06 & .01 & .12 & & & \\
\hline 2 & -3478 & & & & & 4999 & $1277.6^{*}$ & 43.4 \\
\hline$\beta$ & & 46.0 & .2 & 1.1 & & & & \\
\hline t & $15.3^{*}$ & $54.7^{*}$ & .3 & $2.1^{*}$ & & & & \\
\hline S.P.R. & & .65 & .00 & .03 & & & & \\
\hline 3 & 5572 & & & & & 4999 & $258.0^{*}$ & 13.4 \\
\hline$\beta$ & & & -8.6 & 11.9 & 7.7 & & & \\
\hline t & $29.0^{*}$ & & 11.8 & 20.6 & 14.9 & & & \\
\hline S.P.R. & & & -.18 & .20 & .23 & & & \\
\hline 4 & -4444 & & & & & 4999 & $1329.2^{*}$ & 44.4 \\
\hline$\beta$ & & 45.1 & -2.6 & & 3.8 & & & \\
\hline $\mathrm{t}$ & $18.6^{*}$ & $58.7^{*}$ & $4.4^{*}$ & & $9.6^{*}$ & & & \\
\hline S.P.R. & & .64 & -.06 & & .12 & & & \\
\hline 5 & -4451 & & & & & 4999 & $1318.4^{*}$ & 44.2 \\
\hline$\beta$ & & 45.1 & & .7 & 3.1 & & & \\
\hline $\mathrm{t}$ & $18.3^{*}$ & $54.4^{*}$ & & 1.4 & $8.3^{*}$ & & & \\
\hline S.P.R. & & .64 & & .02 & .09 & & & \\
\hline 6 & -7948 & & & & & 4999 & $265.0^{*}$ & 9.6 \\
\hline$\beta$ & & & -3.3 & 12.9 & & & & \\
\hline t & $73.4^{*}$ & & $5.0^{*}$ & $22.6^{*}$ & & & & \\
\hline S.P.R. & & & -.07 & .30 & & & & \\
\hline 7 & -3557 & & & & & 5000 & $1912.4^{*}$ & 43.3 \\
\hline$\beta$ & & 46.6 & .2 & & & & & \\
\hline $\mathrm{t}$ & $16.0^{*}$ & $61.6^{*}$ & .5 & & & & & \\
\hline S.P.R. & & .66 & .01 & & & & & \\
\hline 8 & 6545 & & & & & 5000 & $160.2^{*}$ & 6.0 \\
\hline$\beta$ & & & -.9 & & 9.1 & & & \\
\hline $\mathrm{t}$ & $33.8^{*}$ & & $12.3^{*}$ & & $17.3^{*}$ & & & \\
\hline S.P.R. & & & -.19 & & .27 & & & \\
\hline 9 & -3450 & & & & & 5000 & $1916.6^{*}$ & 43.4 \\
\hline$\beta$ & & 45.7 & & 1.1 & & & & \\
\hline $\mathrm{t}$ & $16.2^{*}$ & $55.0^{*}$ & & 2.1 & & & & \\
\hline S.P.R. & & .65 & & .03 & & & & \\
\hline 10 & 5863 & & & & & 5000 & $309.1^{*}$ & 11.0 \\
\hline$\beta$ & & & & 12.1 & 4.6 & & & \\
\hline t & $30.4^{*}$ & & & $20.9^{*}$ & $10.2^{*}$ & & & \\
\hline S.P.R. & & & & .28 & .14 & & & \\
\hline
\end{tabular}

${ }^{1}$ Squared multiple correlation coefficients.

${ }^{2}$ d.f., degrees of freedom.

${ }^{3}$ Intercept (lb milk).

$\dagger$ Regression coefficients (lb milk/day).

$\dagger t$ values.

$\dagger$ † Standard partial correlation coefficients.

$* \mathrm{P}<.05$. 
TABLE 2-Continued

\begin{tabular}{lrrrrrrrr}
\hline Combination & $\alpha^{1}$ & $\begin{array}{c}\text { Lactation } \\
\text { length }\end{array}$ & $\begin{array}{c}\text { Days } \\
\text { dry }\end{array}$ & $\begin{array}{c}\text { Days } \\
\text { open }\end{array}$ & $\begin{array}{c}\text { Calving } \\
\text { interval }\end{array}$ & $\begin{array}{c}\text { Denominator } \\
\text { d.f. }\end{array}$ & $F$-ratio & $R^{2} \%^{3}$ \\
\hline 11 & -4510 & & & & & 5000 & $1976.4^{*}$ & 44.2 \\
$\beta$ & & 45.6 & & 3.0 & & & \\
$t$ & $18.9^{*}$ & $60.6^{*}$ & & $8.5^{*}$ & & & \\
S.P.R. & & .65 & & .09 & & & \\
\hline
\end{tabular}

The contribution of days open to the variance in milk yield has been reported as small, about 2.0 to $6.5 \%(9,17,20)$. As the number of days open increases, cumulative milk production also tends to increase (18). Some reports give more importance to days open than is warranted from the present study. Some authors have gone so far as to recommend that days open should be considered in evaluating dairy records $(16,19)$.

The results of regression lactation length, days dry, days open, and calving interval on fat yield revealed essentially the same picture as for milk yield (table 3 ). All regressions were significant $(\mathrm{P}<.05)$. The combined contribution of days dry, days open, and calving interval to the variation in fat yield was of the same magnitude as in milk yield, but lactation length had an $R^{2}$ value 5 to $6 \%$ less than for milk yield. The regressions indicate that fat yield would be increased about $1 \mathrm{lb}$ if lactation length was increased by 1 day, whereas a change of 1 day in the other variable would essentially have no influence. The ranking in the order of magnitude of the contribution of the independent variables to fat yield remained unchanged from that for milk with the exception that days open influenced fat yield significantly but not milk yield. These findings parallel temperate data as was indicated for milk yield $(7,14$, 16).

The effects of lactation length, days dry, days open, and calving interval on fat percent were small (table 4). All the values for $R^{2}$ were less than $0.25 \%$. The significant regressions had days dry as an independent variable in the equation. Days open, together with days dry and lactation length, had a greater influence than combinations with calving interval. In order of magnitude of contribution to the variation in fat percent were days dry, lactation length, days open. and calving interval. Length of the previous dry period and current days open increased fat percent, while increased lactation length and calving interval tended to depress fat percent. The calculated $\beta$ values were extremely small.

Most studies have indicated that length of dry period plays an important part in lactation performance; but in this study, its effect was significant only when calving interval was included as an independent variable. The influence of calving interval on the variation in yields of milk and fat was significant with any combination of variables, except 
TABLE 3.-Regression coefficients for predicting fat yield (dependent variable) from various combinations of lactation length, days dry, days open, and calving interval (independent variables) and test of significance

\begin{tabular}{|c|c|c|c|c|c|c|c|c|}
\hline Combination & $\alpha^{1}$ & $\begin{array}{l}\text { Lactation } \\
\text { length }\end{array}$ & $\begin{array}{l}\text { Days } \\
\text { dry }\end{array}$ & $\begin{array}{l}\text { Days } \\
\text { open }\end{array}$ & $\begin{array}{l}\text { Calving } \\
\text { interval }\end{array}$ & $\begin{array}{c}\text { Denominator } \\
\text { d.f. }{ }^{2}\end{array}$ & $F$-ratio & $R^{23}$ \\
\hline 1 & -144.1 & & & & & 4998 & $776.2^{*}$ & 38.0 \\
\hline$\beta \dagger$ & & 1.3 & -0.1 & 0.1 & 0.1 & & & \\
\hline $\mathrm{t}+\dagger$ & $16.3^{*}$ & $45.3^{*}$ & $3.5^{*}$ & $2.7^{*}$ & $9.2^{*}$ & & & \\
\hline S.P.R.t十† & & .57 & -.05 & .03 & .12 & & & \\
\hline 2 & -122.3 & & & & & 4999 & $976.7^{*}$ & 37.0 \\
\hline$\beta$ & & .1 & .1 & .1 & & & & \\
\hline t & $13.7^{*}$ & $47.1^{*}$ & 1.3 & $3.29 *$ & & & & \\
\hline S.P.R. & & .60 & .00 & .04 & & & & \\
\hline 3 & 166.1 & & & & & 4999 & $1017.7^{*}$ & 12.4 \\
\hline$\beta$ & & & -.2 & .4 & .2 & & & \\
\hline $\mathrm{t}$ & $25.1^{*}$ & & $10.3^{*}$ & $19.9^{*}$ & $14.3^{*}$ & & & \\
\hline S.P.R. & & & -.16 & .27 & .22 & & & \\
\hline 4 & -148.4 & & & & & 4999 & $1017.7^{*}$ & 37.9 \\
\hline$\beta$ & & 1.4 & -.1 & & .1 & & & \\
\hline t & $17.1^{*}$ & $51.1^{*}$ & $3.4^{*}$ & & $9.1^{\circ}$ & & & \\
\hline S.P.R. & & .59 & -.04 & & .12 & & & \\
\hline 5 & -146.1 & & & & & .4939 & $1015.2^{*}$ & 37.9 \\
\hline$\beta$ & & 1.4 & & .1 & .1 & & & \\
\hline t & $16.6^{*}$ & $46.8^{*}$ & & $2.6^{*}$ & $8.6^{*}$ & & & \\
\hline S.P.R. & & .58 & & .03 & .10 & & & \\
\hline 6 & 245.3 & & & & & 5000 & $243.6^{*}$ & 8.9 \\
\hline$\beta$ & & & -.1 & .4 & & & & \\
\hline t & $65.7^{*}$ & & $3.7^{*}$ & $21.9^{*}$ & & & & \\
\hline S.P.R. & & & -.05 & .30 & & & & \\
\hline 7 & 116.9 & & & & & 5000 & $1456.8^{*}$ & 36.8 \\
\hline$\beta$ & & 1.4 & .0 & & & & & \\
\hline $\mathrm{t}$ & $14.4^{*}$ & $53.9^{*}$ & 1.6 & & & & & \\
\hline S.P.R. & & .61 & .02 & & & & & \\
\hline 8 & 198.6 & & & & & 5000 & $145.5^{*}$ & 5.5 \\
\hline$\beta$ & & & -.2 & & .3 & & & \\
\hline $\mathrm{t}$ & $29.8^{*}$ & & $10.9 *$ & & $16.8^{*}$ & & & \\
\hline S.P.R & & & -.17 & & .27 & & & \\
\hline 9 & 174.9 & & & & & 5000 & $296.8^{*}$ & 10.6 \\
\hline$\beta$ & & & & .4 & .2 & & & \\
\hline $\mathrm{t}$ & $26.3^{*}$ & & & $20.2^{*}$ & $10.5^{*}$ & & & \\
\hline S.P.R. & & & & .27 & .14 & & & \\
\hline 10 & -108.5 & & & & & .3000 & $146,9 *$ & 36.9 \\
\hline$\beta$ & & 1.4 & & .1 & & & & \\
\hline $\mathrm{t}$ & $14.1^{*}$ & $47.3^{*}$ & & $3.4^{*}$ & & & & \\
\hline S.P.R. & & .59 & & .04 & & & & \\
\hline
\end{tabular}

${ }^{1}$ Squared multiple correlation coefficients.

${ }^{2}$ d.f., degrees of freedom.

${ }^{3}$ Intercept (lb fat).

$\dagger$ Regression coefficients (lb fat/day).

$\dagger \dagger t$ values.

†† Standard partial correlation coefficients.

$* \mathrm{P}<.05$. 
TABLE 3-Continued

\begin{tabular}{|c|c|c|c|c|c|c|c|c|}
\hline Combination & $\alpha^{1}$ & $\begin{array}{l}\text { Lactation } \\
\text { length }\end{array}$ & $\begin{array}{l}\text { Days } \\
\text { dry }\end{array}$ & $\begin{array}{l}\text { Days } \\
\text { open }\end{array}$ & $\begin{array}{l}\text { Calving } \\
\text { interval }\end{array}$ & $\begin{array}{l}\text { Denominator } \\
\text { d.f. }{ }^{2}\end{array}$ & $F$-ratio & $R^{23}$ \\
\hline 11 & -150.2 & & & & & 5000 & $1517.6^{*}$ & 37.8 \\
\hline$\beta$ & & 1.4 & & & .1 & & & \\
\hline $\mathrm{t}$ & $17.32^{*}$ & $52.7^{*}$ & & & 3.9 & & & \\
\hline S.P.R. & & .59 & & & .1 & & & \\
\hline
\end{tabular}

when lactation length was excluded from the model, (tables 2 and 3). This suggests that long dry periods influence yields only when associated with short calving intervals. This is contrary to the findings of Fryman (5) and McIntyre (8). A positive correlation between dry period prior to a lactation and the calving interval indicates that the lengthening of the calving interval is associated with a lengthening of the dry period (table 1). Since the length of the previous lactation is a component of the calving interval, this implies that the previous lactation length would have likely been shorter than 305 days. The correlations lend support to this hypothesis (table 1). Possibly the influence on a subsequent lactation, attributed to the length of the dry period and calving interval, is really a function of the short lactation preceding it, which under the usual feeding regime in Puerto Rico would give the cow a better opportunity to recuperate its body reserves (2). There is evidence that high production is negatively related to reproductive performance (6), but in Puerto Rico days open had a nonsignificant influence on either milk or fat yields. Therefore, selection with emphasis on lactation yields is unlikely to decrease fertility (4).

\section{RESUMEN}

Se utilizaron los registros de producción de vacas Holstein puras o de alto grado de pureza en 62 hatos del programa oficial para el mejoramiento de hatos lecheros. El propósito fue determinar las correlaciones fenotípicas de la duración de lactación, el período seco antes de la lactación, el período receptivo durante la lactación y el intervalo de pariciones previas (intervalo entre partos) con la producción de leche y grasa y porcentaje de grasa. La producción de leche y grasa arrojó una correlación fenotípica significativa ( $\mathrm{P}<$ .05) y positiva con la duración de lactación, intervalo entre partos y días receptivos $(+0.178$ $a+0.658$ ), mientras que el porcentaje de grasa arrojó una baja relación con estas variables $(-0.023 \mathrm{a}+0.014)$.

Se determinó la regresión entre la duración de la lactación, días secos, días receptivos y el intervalo entre partos con la producción de leche y grasa y el porcentaje de grasa. La contribución combinada de estas variables a la variación en producción de leche fue $44.4 \%$. El período receptivo, el período seco y el intervalo entre partos explicaron solamente el $13.4 \%$ de la variación en producción de leche. Los períodos receptivo y seco juntos explicaron el $9.6 \%$ de la variación y el período seco, más el intervalo entre partos, explicaron el $6.0 \%$ de la variación. Los valores de producción de grasa fueron ligeramente más bajos, 
TABLE 4.-Regression coefficients for predicting fat percent (independent variable) irom various combinations of lactation length, days dry, days open and calving interval (independent variables), and test of significance

\begin{tabular}{|c|c|c|c|c|c|c|c|c|}
\hline Combination & $\alpha^{1}$ & $\begin{array}{l}\text { Lactation } \\
\text { length }\end{array}$ & $\begin{array}{l}\text { Days } \\
\text { dry }\end{array}$ & $\begin{array}{l}\text { Days } \\
\text { open }\end{array}$ & $\begin{array}{l}\text { Calving } \\
\text { interval }\end{array}$ & $\begin{array}{l}\text { Denomi- } \\
\text { nator d.f. }\end{array}$ & $F$-ratio & $R^{23}$ \\
\hline 1 & 2.8 & & & & & 4998 & $2.88^{*}$ & 0.23 \\
\hline$\beta \dagger$ & & -0.0003 & 0.0003 & 0.0001 & -0.0000 & & & \\
\hline $\mathrm{t}+t$ & $57.8^{*}$ & 1.75 & 2.29 & 1.37 & .24 & & & \\
\hline S.P.R.†† & & -.03 & .04 & .02 & -.00 & & & \\
\hline 2 & 2.8 & & & & & 4999 & $3.82^{*}$ & 23 \\
\hline$\beta$ & & -.0003 & .0003 & .0001 & & & & \\
\hline t & $62.9^{*}$ & 1.81 & 2.53 & 1.35 & & & & \\
\hline S.P.R, & & & & & & & & \\
\hline 3 & 2.7 & & & & & 4999 & $2.82^{*}$ & 17 \\
\hline$\beta$ & & & .0003 & .0001 & -.0000 & & & \\
\hline $\mathrm{t}$ & $89.6^{*}$ & & $2.68^{*}$ & .70 & .54 & & & \\
\hline S.P.R. & & & .04 & .01 & -.01 & & & \\
\hline 4 & 2.7 & & & & & 4999 & $3.21^{*}$ & .19 \\
\hline$\beta$ & & -.0002 & .0003 & & -.0000 & & & \\
\hline $\mathrm{t}$ & $58.7^{*}$ & 1.30 & 2.35 & & .16 & & & \\
\hline S.P.R. & & -.02 & .04 & & -.00 & & & \\
\hline 5 & 2.8 & & & & & 4999 & 2.07 & .12 \\
\hline$\beta$ & & -.0004 & & .0001 & .0001 & & & \\
\hline $\mathrm{t}$ & $58.2^{*}$ & 2.22 & & 1.44 & 1.08 & & & \\
\hline S.P.R. & & -.04 & & .02 & .02 & & & \\
\hline 6 & 2.7 & & & & & 5000 & $4.08^{*}$ & .16 \\
\hline$\beta$ & & & .0003 & .0001 & & & & \\
\hline t & $161.3^{*}$ & & 2.77 & .63 & & & & \\
\hline S.P.R. & & & .04 & .01 & & & & \\
\hline 7 & 2.4 & & & & & 5000 & $4.81^{*}$ & .19 \\
\hline$\beta$ & & -.0002 & .0003 & & & & & \\
\hline $\mathrm{t}$ & $63.6^{*}$ & 1.30 & $2.64^{*}$ & & & & & \\
\hline S.P.R. & & -.02 & .04 & & & & & \\
\hline 8 & 2.7 & & & & & 5000 & $3.98 *$ & .16 \\
\hline$\beta$ & & & .0003 & & -.0000 & & & \\
\hline $\mathrm{t}$ & $92.6^{*}$ & & 2.64 & & .44 & & & \\
\hline S.P.R. & & & .04 & & -.01 & & & \\
\hline 9 & 2.8 & & & & & 5000 & 2.58 & .10 \\
\hline$\beta$ & & -.0003 & & $.000^{\prime 2}$ & & & & \\
\hline$t$ & $67.6^{*}$ & $2.13^{*}$ & & 1.55 & & & & \\
\hline S.P.R. & & -.03 & & .02 & & & & \\
\hline 10 & 2.7 & & & & & 5000 & .65 & .03 \\
\hline$\beta$ & & & & .0001 & .0001 & & & \\
\hline t & $89.9 *$ & & & .57 & .89 & & & \\
\hline S.P.R. & & & & .01 & .01 & & & \\
\hline
\end{tabular}

${ }^{1}$ Squared multiple correlation coefficients.

${ }^{2}$ d.f., degrees of freedom.

${ }^{3}$ Intercept (\% fat).

$\dagger$ Regression coefficients (\% fat).

计 $t$ values.

$\dagger+\dagger$ Standard partial correlation coefficients.

${ }^{*} \mathrm{P}<.05$. 
TABLE 4-Continued

\begin{tabular}{l|c|c|c|c|c|c|c|c}
\hline Combination & $\alpha^{\prime}$ & $\begin{array}{c}\text { Lactation } \\
\text { length }\end{array}$ & $\begin{array}{c}\text { Days } \\
\text { dry }\end{array}$ & $\begin{array}{c}\text { Days } \\
\text { open }\end{array}$ & $\begin{array}{c}\text { Calving } \\
\text { interval }\end{array}$ & $\begin{array}{c}\text { Denomi- } \\
\text { nator d.f. }\end{array}$ & $F$-ratio & $R^{23}$ \\
\hline 11 & 2.7 & & & & & & & \\
$\beta$ & & -.0003 & & & .0001 & & 2.06 & .08 \\
t & $58.9^{*}$ & 1.78 & & & 1.22 & & & \\
S.P.R. & & -.03 & & & .02 & & & \\
\hline
\end{tabular}

pero presentaron un patrón similar que los de producción de leche. Las cuatro variables combinadas contribuyeron solamente con el $0.23 \%$ a la variación en porcentaje de grasa. Las producciones totales de leche y grasa dependieron de la duración de la lactación, el intervalo entre partos y los días secos en orden descendente de magnitud. El período receptivo tuvo una influencia relativamente pequeña en las producciones de leche o grasa. La longitud del período seco afectó el porcentaje de grasa más que cualquier otra variable aunque de una manera insignificante. Como la mayoría de la variación en las producciones de leche y grasa atribuida a las cuatro variables fue debida a la duración de la lactación, parece improbable que en Puerto Rico la selección basada principalmente en la producción de leche disminuya la fertilidad.

\section{LITERATURE CITED}

1. Brown, C. A., and White, J. M., Management factors associated with herd average milk yield and income over feed costs in Guernsey, Holstein and Jersey herds, J. Dairy Sci., 56: 789-98, 1973.

2. Camoens, J. K., McDowell, R. E., VanVleck, L. D., and Rivera Anaya, J. D., Holsteins in Puerto Rico. I. Influence of herd, year, age, and season on performance, J. Agr. Univ. P. R. 60 (4): 526-39, 1976.

3. Dickinson, F. N., McDaniel, B. T., and McDowell, R. E., Comparative efficiency of feed utilization during first lactation of Ayrshire, Brown Swiss and Holstein cows, J. Dairy Sci., 52: 489-97, 1969.

4. Foote, R. H., Inheritance of fertility-facts, opinions, and speculations, J. Dairy Sci., 52: 936-44, 1970.

5. Fryman, L. R., The influence of selected management practices on FCM production of Illinois Holstein cows, Diss. Abstr. Int. B 32: 3092-B, 1971.

6. Matsoukas, J., and Fairchild, T. P., Effects of various factors on reproductive efficiency, J. Dairy Sci., 56: 1381, 1973.

7. McDowell, R. E., Improvement of livestock production in warm climates, W. H. Freeman \& Co., San Francisco, 1972.

8. McIntyre, K. H., Milk production of Bos taurus cattle in Fiji, Trop. Agr. Trin. 48: $317-26,1971$.

9. Miller, R. H., and Hooven, N. W., Factors affecting whole and part lactation milk yield and fat percentage in a herd of Holstein cattle, J. Dairy Sci., 52: 1025-36, 1967.

10. Miller, P. D., VanVleck, L. D., and Henderson, C. R., Relationships among herd life, milk production and calving interval, J. Dairy Sci., 50: 1283-7, 1967.

11. Ngere, L. O., McDowell, R. E., Bhattacharya, S., and Guha, S., Factors influencing milk yield of Hariana cattle, J. Anim. Sci., 36: 457-65, 1973.

12. Olds, D., and Cooper, T., Factors affecting calving intervals in Kentucky Dairy Herd Improvement Association herds, J. Dairy Sci., 53: 670, 1970.

13. Pobric, F., and Mutevelic, A., Relationship between length of service period and milk production in the first 120 days of lactation in Friesian heifers, Vet. Saraj., 19: 589-96, 1970. 
14. Rathore, A. K., The influence of dry period on milk yield and composition, XVIII Int. Dairy Congr. Proc., Sydney, Australia, Vol. 1E: 581, 1970.

15. Rice, V. A., Andrews, F. N., Warwick, E. J., and Legates, J. E., Breeding and improvement of farm animals, 6th ed, McGraw-Hill, N.Y., 1967.

16. Ripley, R. L., Tucker, W. L., and Voelker, H. H., Effect of days open on lactation production, J. Dairy Sci., 53: 673, 1970.

17. Sargent, F. D., Butcher, K. R., and Legates, J. E., Environmental influences on milk constituents, J. Dairy Sci., 50: 177-84, 1967.

18. Schaeffer, L. R., and Henderson, C. R., Effects of days dry and days open on Holstein milk production, J. Dairy Sci., 55: 107-12, 1972.

19. - Everett, R. W., and Henderson, C. R. Lactation records adjusted for days open, J. Dairy Sci., 56: 602-7, 1973.

20. Smith, J. W., and Legates, J. E., Relation of days open, days dry to lactation, milk and fat yields, J. Dairy Sci., 45: 1192-8, 1962. 